\title{
KADAR APOLIPOPROTEIN B 100 SERUM PADA PENDERITA NEFROPATI DIABETIKUM
}

\author{
Eva Decroli
}

\begin{abstract}
Abstrak
Penelitian ini bertujuan untuk mengetahui kadar Apolipoprotein B 100 serum pada penderita nefropati diabetikum. Metode penelitian ini dengan desain cross sectional yang bersifat deskriptif analitik. Populasi adalah semua pasien yang menderita diabetes mellitus tipe 2 yang dirawat di bagian penyakit dalam atau kontrol ke poliklinik khusus metabolik endokrin RSU Dr. M. Djamil Padang. Sampel penelitian adalah pasien diabetes mellitus tipe 2 dengan proteinuria positif yang memenuhi kriteria inklusi dan ekslusi yang diambil secara konsekutif. Sampel penelitian diambil dari darah vena dalam keadaaan puasa selama 12 jam. Pemeriksaan apolipoprotein B 100 serum dilakukan di laboratorium klinik swasta, dengan menggunakan metode imunoturbidimetri. Albumin creatinin ratio merupakan perbandingan kadar albumin urin terhadap kreatinin urin dengan metode pemeriksaan imunoturbidimetri. Pada penelitian ini didapatkan rerata kadar Apolipoprotein B 100 serum yaitu $86,10 \mathrm{mg} / \mathrm{dl}$ (nilai normal $66-101 \mathrm{mg} / \mathrm{dl}$ ) dengan standar deviasi 27,997. Simpulan: Tidak terdapat peningkatan kadar apolipoprotein B 100 serum pada penderita nefropati diabetikum.
\end{abstract}

Kata kunci: Apolipoprotein B 100, albumin creatinine ratio, nefropati diabetikum

\begin{abstract}
This study aims to examine Apolipoprotein B 100 serum level in diabetic nephropathy patient. Study design was cross sectional with analytic descriptive. Population is all type 2 diabetes mellitus inpatient and outpatient in internal medicine M Djamil hospital. Sample is all type 2 diabetes mellitus consecutive patient with positive proteinuria and fullfilled inclusion and exclusion criteria. Vein blood was taken after 12 hours-fasting. Apolipoprotein B 100 serum check at non-governmental laboratory by immunoturbidimetry methode. Albumin creatinin ratio check by immunoturbidimetry methode. Result: Apolipoprotein B 100 serum level is $86.10 \mathrm{mg} / \mathrm{dl}$ (normal value 66-101 mg/dl) with standar deviation 27.997. Conclusion: There is no significant enhancement of apolipoprotein $B 100$ serum level in diabetic nephropathy patient.
\end{abstract}

Keywords : Apolipoprotein B 100, albumin creatinine ratio, diabetic nephropathy

Afiliasi Penulis : Sub Bagian Endokrin Metabolik Bagian Penyakit Dalam RSUP Dr. M. Djamil Padang/ Fakultas Kedokteran Universitas Andalas. Korespondensi: Eva Decroli, Bagian IImu Penyakit Dalam Fakultas Kedokteran Universitas Andalas, JI Perintis Kemerdekaan no. 94 Padang. Email: eva.decroli@yahoo.com, Telp\HP: 0811936846 


\section{PENDAHULUAN}

Diabetes melitus (DM) merupakan suatu kelompok penyakit metabolik dengan karakteristik hiperglikemia yang terjadi karena kelainan sekresi insulin, kerja insulin atau kedua-duanya. ${ }^{1}$ Prevalensi diabetes melitus terus meningkat di seluruh dunia. Diperkirakan saat ini terdapat 285 juta orang menderita diabetes diseluruh dunia dan angka ini terus meningkat mencapai 438 juta pada tahun 2030. ${ }^{2}$ Peningkatan tajam insiden diabetes ini $70-80 \%$ terjadi di negara berkembang sedangkan di negara maju lebih kurang 20\%. ${ }^{2,3}$ Menurut World Health Organization (WHO), Indonesia menempati peringkat keempat jumlah pasien diabetes terbanyak di dunia setelah India, China dan Amerika Serikat (AS).4,5 Jumlah penderita DM Tipe 2 di Indonesia pada tahun 2000 adalah 8,4 juta orang dan diperkirakan jumlah ini akan meningkat pesat menjadi 21,3 juta orang pada tahun $2030 .{ }^{6}$ Lebih dari $90 \%$ pasien diabetes adalah pasien diabetes melitus tipe 2 (DMT2). ${ }^{5}$

Sekitar 3,2 juta kematian setiap tahun diakibatkan oleh komplikasi diabetes dan terjadi enam kematian setiap menit akibat diabetes. Menurut Centers for Disease Control (CDC), diabetes adalah penyebab ketujuh kematian di AS. ${ }^{4,5}$ Komplikasi Diabetes Melitus terdiri dari komplikasi mikroangiopati dan komplikasi makroangiopati. Komplikasi mikroangiopati yang terbanyak adalah nefropati diabetes (ND), berhubungan dengan kematian yang tinggi pada pasien diabetes dan merupakan penyebab utama dari penyakit ginjal tahap akhir (PGTA), dimana prevalensinya $40 \%$ dari penyakit ginjal tahap akhir. ${ }^{6,7,8}$
Penyakit ginjal kronik (PGK) tahap akhir menjadi masalah yang besar oleh karena prevalensinya yang semakin meningkat di seluruh dunia. ${ }^{3}$ Menurut data National Health and Nutrition Examination Survey (NHANES) tahun 1999-2004, prevalensi PGK diantara populasi Amerika adalah $15,3 \% .^{5}$ Saat ini PGK sudah menjadi ancaman bagi kesehatan masyarakat, walaupun besaran dimensinya belum begitu jelas. ${ }^{6} \mathrm{Di}$ seluruh dunia diperkirakan saat ini terdapat 1,8 juta yang mendapat pengobatan pengganti ginjal, mencakup yang menjalani dialisis dan transplantasi, lebih dari 90\% diantaranya berada di negara maju. Sedangkan prevalensi di negara yang berkembang saat ini meningkat dengan cepat seiring dengan kemajuan ekonomi. ${ }^{7,8}$

Bila albumin di urin $30-300$ $\mathrm{mg} / \mathrm{hari}$, hal ini disebut mikroalbuminuria, ${ }^{9}$ sedangkan American Diabetes Association (ADA), National Kidney Foundation (NKF), Kidney Disease Outcome Quality Initiative (KDOQI), The Joint National Comittee 7 (JNC 7) merekomendasikan pemeriksaan albumin creatinin ratio (ACR) dari sampel urin pagi untuk pemeriksaan mikroalbuminuria. ${ }^{10,11}$ Pemeriksaan ACR umumnya digunakan sebagai pengganti pemeriksaan kadar albumin urin 24 jam mengingat sulitnya pengumpulan urin 24 jam. ${ }^{12,13}$ Nefropati diabetes dapat dikurangi progresivitasnya dengan pengontrolan gula darah, tekanan darah, dan lipid darah yang ketat. ${ }^{14}$

Pada tahun 1982, Moorhead et al mengemukakan hipotesis bahwa lipid plasma yang tinggi dapat merusak ginjal. ${ }^{15} \mathrm{Di}$ dalam darah terdapat apolipoprotein, yaitu senyawa lipid dengan apoprotein. ${ }^{16}$ Apolipoprotein $B$ merupa- 
kan protein yang besar dalam plasma yang ada dalam 2 bentuk yaitu apo B 48 dan apo B 100. Apo B 48 khususnya ditemukan di intestinal dan bekerja membawa kilomikron, sementara Apo B 100 terutama dihasilkan di hati dan berada pada semua partikel lipoprotein yang aterogenik seperti VLDL, IDL, LDL dan lipoprotein a. Apolipoprotein B 100 merupakan salah satu rantai polipeptida tunggal terpanjang yang memiliki 4536 asam amino, disintesis oleh ribosom di retikulum endoplasma kasar parenkim hati, beratnya 550.000 Da. Apolipoprotein B 100 (apo B 100) merupakan apolipoprotein primer dari LDL, yang bertanggung jawab membawa kolesterol ke jaringan. ${ }^{17,18}$

Pada DM tipe 2 terjadi peningkatan Apolipoprotein B 100. Hal ini disebabkan karena penurunan degradasi dan peningkatan sekresi Apo B akibat adanya resistensi insulin dan penurunan klirens Apo B. ${ }^{19}$

Samuelsson et al (1998) melakukan penelitian terhadap pasien DM tipe 2 dan mendapatkan adanya hubungan antara Apolipoprotein B dengan penurunan fungsi ginjal. ${ }^{20}$ Uniyal et al (2012) melakukan penelitian terhadap 100 orang penderita DM tipe 2, dan menyimpulkan bahwa apoprotein B yang tinggi berhubungan dengan kejadian nefropati diabetikum. ${ }^{21}$

Berbeda dengan penelitian oleh Adi S dkk (2012) yang melakukan penelitian terhadap 40 orang penderita DM Tipe 2 dan mendapatkan bahwa tidak ada korelasi antara Apo B 100 serum dengan albuminuria. ${ }^{22}$ Nakhjavani et al (2008) juga melakukan penelitian terhadap 400 orang penderita DM tipe 2 dan mendapatkan bahwa tidak ada kore- lasi antara Apo B dengan peningkatan albuminuria. $^{23}$

Berdasarkan latar belakang masalah di atas kami ingin melakukan penelitian untuk melihat kadar Apolipoprotein B 100 serum dengan kadar albumin urin pada pasien nefropati diabetikum. Penelitian ini bertujuan untuk mengetahui kadar Apolipoprotein B 100 serum pada penderita nefropati diabetikum.

\section{METODE}

Penelitian ini dengan desain cross sectional yang bersifat deskriptif analitik. Populasi adalah semua pasien yang menderita diabetes mellitus tipe 2 yang dirawat di bagian penyakit dalam atau kontrol ke poliklinik khusus metabolik endokrin RSU Dr. M. Djamil Padang. Sampel penelitian adalah pasien diabetes mellitus tipe 2 dengan proteinuria positif yang memenuhi kriteria inklusi dan ekslusi yang diambil secara konsekutif.

Kriteria inklusi penelitian ini adalah pasien DM tipe 2 berdasarkan kriteria Perkeni 2011 dengan mikroalbuminuria dan makroalbuminuria dan ditemukan retinopati diabetika dan bersedia ikut dalam penelitian. Kriteria eksklusi terdiri dari penyakit hati kronik, payah jantung, infeksi saluran kencing, sindrom nefrotik, sesudah olahraga berat.

Sampel penelitian diambil dari darah vena dalam keadaaan puasa selama 12 jam. Pemeriksaan dilakukan di laboratorium klinik swasta, dengan menggunakan metode imunoturbidimetri. ACR merupakan perbandingan kadar albumin urin terhadap kreatinin urin dengan metode pemeriksaan imunoturbidimetri. 
Dilakukan analisis statistik deskriptif terhadap data dasar yang meliputi karakteristik penderita. Data yang bersifat kategorik ditampilkan dalam bentuk frekuensi dan persentase, sedangkan data yang bersifat numerik ditampilkan dalam bentuk rerata dan standar deviasi. Pada data numerik dilakukan uji normalitas menggunakan uji Kolmogorov Smirnov. Data diolah dengan SPSS 17.0. Telah dilakukan penelitian terhadap 30 orang pasien nefropati diabetika, pengumpulan sampel dilaksanakan dari bulan Juni sampai September 2014.

\section{HASIL DAN PEMBAHASAN}

Tabel 1 menyajikan gambaran karakteristik 30 orang subyek penelitian. Karakteristik meliputi umur, jenis kelamin, indeks massa tubuh, hipertensi, lama DM, dislipidemia dan $\mathrm{HbA1c}$. Pada penelitian ini didapatkan umur rerata subyek penelitian adalah 56,9 $(7,5)$ tahun, umur termuda 40 tahun dan umur tertua 72 tahun. Kelompok umur terbanyak dari sampel yang diteliti adalah rentang umur 50-59 tahun. Distribusi subyek penelitian berdasarkan pembagian kelompok umur adalah sebagai berikut umur 40-49 tahun: 5 orang (17\%), umur 50-59 tahun: 14 orang $(47 \%)$ dan $\geq 60$ tahun: 11 orang $(36 \%)$. Penderita nefropati diabetes pada penelitian ini yang berjenis kelamin perempuan 17 orang (57\%) sedangkan yang berjenis kelamin laki-laki 13 orang (43\%). Rerata indeks massa tubuh pada subyek penelitian adalah 24,4 $(2,9)$ $\mathrm{kg} / \mathrm{m}^{2}$. Sebagian besar subyek tergolong obesitas (IMT > $25 \mathrm{~kg} / \mathrm{m}^{2}$ ) yaitu 17 orang $(56,7 \%)$. Rerata kadar HbA1c pada penelitian ini 8,23 $(1,23) \%$. Pasien dibagi menjadi $\mathrm{HbA} 1 \mathrm{c} \leq 7$ yang berjumlah 5 orang $(16,7 \%)$, dan $\mathrm{HbA} 1 \mathrm{C}>7$ yang berjumlah 25 orang (83,3\%). Jumlah pasien dengan hipertensi pada penelitian ini adalah 19 orang (63,3 \%), sementara yang tidak hipertensi adalah 11 orang (37\%). Rerata lama menderita DM tipe 2 pada subyek penelitian adalah 11,47 $(5,08)$ tahun. Berdasarkan lama menderita DM, pasien dibagi menjadi lama menderita $\mathrm{DM} \leq 5$ tahun yang berjumlah 6 orang $(20 \%)$ dan lama menderita DM > 5 tahun yang berjumlah 24 orang (80\%). Pada penelitian ini sebagian besar pasien digolongkan dislipidemia yaitu berjumlah 17 orang $(56,7 \%)$, sementara yang tidak dislipidemia yaitu 13 orang $(43,3 \%)$.

Tabel 1. Karakteristik Dasar Pasien Nefropati Diabetikum

\begin{tabular}{|c|c|c|}
\hline Karakteristik & n (\%) & $\begin{array}{l}\text { Rerata } \\
\text { (SD) }\end{array}$ \\
\hline $\begin{array}{l}\text { Jenis Kelamin: } \\
\text { Perempuan } \\
\text { Laki-laki }\end{array}$ & $\begin{array}{l}17(57) \\
13(43)\end{array}$ & \\
\hline $\begin{array}{l}\text { Umur (tahun): } \\
40-49 \\
50-59 \\
\geq 60\end{array}$ & $\begin{array}{c}5(17) \\
14(47) \\
11(36)\end{array}$ & $\begin{array}{l}56,87 \\
(7,45)\end{array}$ \\
\hline $\begin{array}{l}\text { IMT }\left(\mathbf{k g} / \mathbf{m}^{2}\right) \text { : } \\
\text { Normal } \\
\text { lebih/obesitas }\end{array}$ & $\begin{array}{l}13(43) \\
17(57)\end{array}$ & $\begin{array}{l}24,39 \\
(2,85)\end{array}$ \\
\hline $\begin{array}{l}\text { Hipertensi : } \\
\text { Tidak } \\
\text { Ya }\end{array}$ & $\begin{array}{l}11(37) \\
19(63)\end{array}$ & \\
\hline $\begin{array}{l}\text { Lama } \\
\text { menderita } \\
\text { (tahun): } \\
\leq 5 \\
>5\end{array}$ & $\begin{array}{l}6(20) \\
24(80)\end{array}$ & $\begin{array}{l}11,47 \\
(5,08)\end{array}$ \\
\hline $\begin{array}{l}\text { HbA1c (\%): } \\
\leq 7 \\
>7\end{array}$ & $\begin{array}{c}5(16,7) \\
25(83,3)\end{array}$ & $\begin{array}{c}8,23 \\
(1,23)\end{array}$ \\
\hline $\begin{array}{l}\text { Dislipidemia: } \\
\text { Tidak } \\
\text { Ya }\end{array}$ & $\begin{array}{c}13(43,3) \\
17(56,67)\end{array}$ & \\
\hline
\end{tabular}


Pada penelitian ini didapatkan rerata kadar Apolipoprotein B 100 serum yaitu $86,10 \mathrm{mg} / \mathrm{dl}$ ( nilai normal 66-101 $\mathrm{mg} / \mathrm{dl}$ ) dengan standar deviasi 27,997.

Gambar 1 menyajikan kurva distribusi dan nilai rerata kadar apolipoprotein B 100 serum. Histogram tersebut memperlihatkan kadar terendah apolipoprotein B 100 serum adalah $33 \mathrm{mg} / \mathrm{dl}$ sedangkan kadar tertinggi adalah 137 mg/dl. Frekuensi Apolipoprotein B 100 terbanyak adalah pada kadar $80 \mathrm{mg} / \mathrm{dl}$ $90 \mathrm{mg} / \mathrm{dl}$. Hasil uji normalitas Kolmogorov Sminorv menunjukkan data kadar apolipoprotein B 100 serum pada penelitian ini berdistribusi normal.

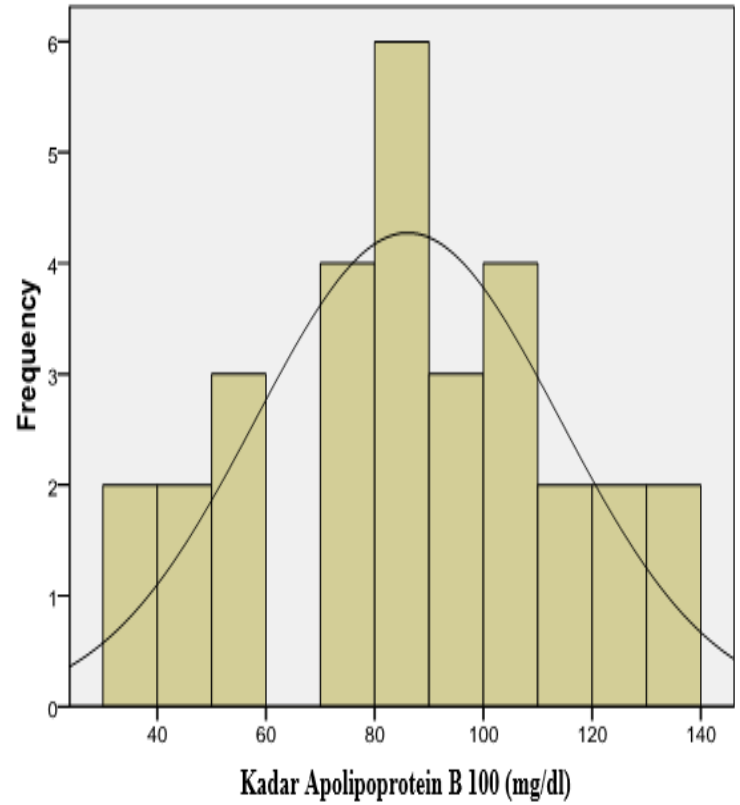

Gambar 1. Kadar apolipoprotein B 100 serum pada pasien nefropati diabetikum

Dari 30 pasien nefropati diabetika, jenis kelamin perempuan lebih banyak dari pada laki-laki dengan rentang usia terbanyak adalah pada rentang umur 5059 tahun. Jumlah pasien dengan berat badan lebih (overweight) - obesitas lebih banyak dibandingkan yang tidak over- weight - obesitas. Jumlah pasien hipertensi lebih banyak dari yang tidak hipertensi. Pasien yang dislipidemia lebih banyak dari yang tidak dislipidemia. Pasien yang keterkontrolan gula darahnya jelek lebih banyak dari yang keterkontrolan gula darahnya baik.

Jumlah pasien perempuan lebih banyak, yaitu 17 orang (57\%) sedangkan pria 13 Orang (43\%). Kejadian nefropati diabetik pada penelitian ini lebih tinggi pada perempuan dibanding pria. Mirip dengan penelitian Tseng $\mathrm{CH}$ (2005) yang melakukan penelitian terhadap 343 pasien DMT2 juga mendapatkan penderita nefropati diabetik lebih banyak perempuan $(58,02 \%)$ dibandingkan lakilaki. ${ }^{24}$

Penelitian Norma S et al (2010) yang melakukan penelitian terhadap 380 pasien DMT2 juga menemukan bahwa lebih banyak perempuan $(60,9 \%)$ dibandingkan dengan laki-laki $(39,1 \%)$ yang mengalami nefropati diabetik. ${ }^{25}$

Bonakdaran et al (2011) yang melakukan penelitian terhadap 1275 pasien DMT2 juga mendapatkan penderita nefropati diabetik lebih banyak perempuan $(56,47 \%)$ dibanding dengan laki-laki $(43,6 \%) .26$

Kelompok umur terbanyak dari penelitian ini adalah pada rentang usia 50-59 tahun yaitu sebanyak 47\%. Hasil yang kita dapatkan sama dengan Gupta et al (2012) yang melakukan penelitian terhadap 100 pasien DMT2 juga mendapatkan kelompok umur 50-59 tahun sebagai kelompok terbanyak $(32,4 \%){ }^{27}$ Penelitian Norma S et al (2010) yang mendapatkan kelompok umur terbanyak adalah 30-39 tahun. ${ }^{25}$

Rerata umur yang kita dapatkan dari penelitian ini adalah 56,87 tahun dengan standar deviasi 7,45 tahun. 
Norma S et al (2010) mendapatkan rerata umur pasien nefropati diabetika 59,9 $(10,7)$ tahun. ${ }^{25}$ Gupta et al (2012) melakukan penelitian terhadap 100 orang penderita DM tipe 2 dan mendapatkan rerata umur 59,15(10,4) tahun. ${ }^{27}$ Rerata umur subyek pada penelitian Norma dan Gupta sedikit lebih tinggi jika dibandingkan dengan penelitian ini. Rerata umur yang hampir sama dengan penelitian kita adalah penelitian oleh Behradmanesh S et al (2013) yang mendapatkan rerata umur pasien DM tipe 2 yang mengalami albuminuria adalah 57(8,3) tahun. ${ }^{28}$ Penelitian Bonakdaran et al (2011) mendapatkan rerata umur $52,45(10,1)$ tahun. ${ }^{26}$ Penelitian Hui-Mei C et al (2013) terhadap 343 pasien DMT2 yang dilakukan selama 6 tahun mendapatkan rerata umur pasien yang mengalami ND adalah 53,1(9,06) tahun. ${ }^{29}$

Rerata Indeks massa tubuh (IMT) pasien pada penelitian ini adalah 24,39 $\mathrm{kg} / \mathrm{m}^{2}$ dengan standar deviasi 2,85. Sebagian besar subyek tergolong pada berat badan lebih (overweight)-obesitas yaitu 17 orang (57\%). Penelitian oleh Pradip et al (2012) menunjukkan rerata indeks massa tubuh pasien nefropati diabetik adalah $28 \mathrm{~kg} / \mathrm{m}^{2} .30$ Penelitian Noha et al (2012) menunjukkan rerata indeks massa tubuh pasien nefropati diabetik 29,9 kg/m². ${ }^{31}$ Penelitian Hui-Mei $C$ et al (2013) juga mendapatkan lebih banyak pasien ND adalah obesitas. ${ }^{29}$ Sylvia et al (2010) juga mendapatkan lebih banyak pasien ND obesitas. ${ }^{32}$

Rerata kadar HbA1c dari penelitian ini adalah 8,23\% dengan standar deviasi 1,23. Dari hasil kadar $\mathrm{HbA1c}$ pada penelitian ini menunjukkan bahwa keterkontrolan gula darah pasien adalah buruk. Penelitian oleh Kundu et al (2013) terhadap 50 pasien DM tipe 2 mendapatkan kadar $\mathrm{HbA1c}$ pasiennya adalah $7,87 \%(1,72) .{ }^{33}$ Juhi et al (2014) melakukan penelitian terhadap pasien DM tipe 2 dan mendapatkan kadar $\mathrm{HbA} 1 \mathrm{c}$ 8,45\% $(1,23) .{ }^{34} \mathrm{Hsu}$ et al (2012) melakukan penelitian terhadap 821 pasien DM tipe 2, mendapatkan kadar $\mathrm{HbA} 1 \mathrm{c}$ pasiennya $8,2 \% \quad(1,8) .{ }^{35}$ Pradip et al (2012) melakukan penelitian terhadap 40 pasien DM tipe 2 dan mendapatkan kadar HbA1c pasiennya adalah $7,6 \%(1,8){ }^{36}$ Noura et al (2014) melakukan penelitian terhadap 51 pasien DM tipe 2 dan mendapatkan kadar HbA1c pasiennya adalah $9,93 \%(1,26){ }^{37}$ Rerata $\mathrm{HbA1c}$ pada penelitian ini dan penelitianpenelitian lainnya di atas menunjukkan hasil yang hampir sama yaitu adanya pengendalian gula darah yang buruk pada pasien nefropati diabetik.

Dari penelitian ini didapatkan jumlah pasien dengan hipertensi yaitu sebanyak 19 orang (63,3\%). Penelitian ChulWoo et al (2011) yang melakukan penelitian terhadap pasien nefropati diabetik, mendapatkan kejadian hipertensi $76,05 \%{ }^{38}$ Penelitian oleh $\mathrm{Hsu}$ et al (2012) juga mendapatkan pasien dengan hipertensi adalah sebanyak 56,1\%. ${ }^{35}$

Banyak dugaan mengenai mekanisme hipertensi pada nefropati diabetika, dan tidak sepenuhnya dipahami, diduga sebagai peranan retensi natrium, aktivasi sistem saraf simpatis dan RAAS serta peningkatan stress oksidatif. Fungsi ginjal yang memburuk berkontribusi dengan terjadinya peningkatan tekanan darah. Prevalensi hipertensi pada nefropati diabetika meningkat seiring dengan peningkatan stadium PGK, mencapai $90 \%$ pada PGTA. ${ }^{39}$

Pada penelitian ini didapatkan kadar rerata apolipoprotein B 100 adalah 
86,10 mg/dl dengan standar deviasi 27,99 . Rerata kadar apolipoprotein pada penelitian ini masih dalam batas normal yaitu 66-101 mg/dl. Pranoto A dkk (2011) juga mendapatkan rerata kadar apolipoprotein B 100 serum dalam batas normal yaitu 93,23 $(29,12) \mathrm{mg} / \mathrm{dl}^{22}$ Bruno $\mathrm{G}$ et al (2003) mendapatkan rerata kadar apolipoprotein B 100 102,2 ( 38,6) mg/dl. ${ }^{40}$ Tseng $\mathrm{CH}$ et al (2009) mendapatkan rerata kadar apolipoprotein B 100 yaitu $113,7(31,9) \mathrm{mg} / \mathrm{dll}^{24}$ Sylvia et al (2010) mendapatkan kadar apolipoprotein B 115 (26). ${ }^{32}$ Nakhjavani (2008) mendapatkan kadar apolipoprotein B yaitu 110,4 $(31,4) \mathrm{mg} / \mathrm{dl} .{ }^{23}$ Chin $(2005)$ mendapatkan kadar apolipoprotein B yaitu 123(37) $\mathrm{mg} / \mathrm{dl}^{41}$ Patel (2012) mendapatkan

\section{DAFTAR PUSTAKA}

1. Deshpande AD, Hayes $M H$, Schoot-man M. Epidemiology of diabetes and diabetes related complication. Phys ther. 2008;58: 1254- 64.

2. Wild S, Roglic G, Green A, Sicree R, King H. Global prevalence of diabetes. Estimates for the year 2000 and projections for 2030 . Diabetes Care. 2004;27:1047-53.

3. Ramachandran A, Snehalatha C, Shetty AS, Nanditha A. Trends in prevalence of diabetes in Asian countries. World J Diabetes. 2012;3: 110-7.

4. International Diabetes Federation. World Diabetes Atlas, $5^{\text {th }}$ Edition. 2011.

5. The epidemiology of type 2 diabetes. Diakses dari http://diabetes.niddk.nih.gov/ U.S. Census Bureau, resident population estimates for 11/1/2007.

6. Prevalensi DM Indonesia Kementerian Kesehatan RI. Diakses dari www.depkes.go.id

7. Hall PM. Prevention of progression in diabetic nephropthy. Diabetes Spectr. 2006;19:18-24.

8. Adler Al, Stevens RJ, Manley SE. Development and progression of Nephropathy in type 2 diabetes:UKPDS.Kidney Int.2003;63:225-32 kadar apolipoprotein B yaitu $119(0,5)$ mg/dl. ${ }^{42}$ Rizk (2012) mendapatkan kadar apolipoprotein B yaitu 140 $(0,48) .{ }^{43}$ Corseti (2014) mendapatkan kadar apolipoprotein B yaitu $111(0,32) .{ }^{44}$ Lam (1996) mendapatkan kadar apoliprotein B yaitu $134 \mathrm{mg} / \mathrm{dl}^{4}{ }^{42}$ Penelitian Adi S sama dengan penelitian ini dimana Adi $S$ mendapatkan kadar apolipoprotein B 100 serumnya dalam batas normal.

\section{SIMPULAN}

Penelitian ini menunjukkan tidak terdapat peningkatan kadar apolipoprotein B 100 serum pada penderita nefropati-diabetikum.

9. Go AS, Chertow GM, Fan D, Mculloch CE, Hsu CY. Chronic kidney disease and the risk of death, cardiovascular events, and hospitalization. N Engl J Med. 2004;351:1296-1305

10. Remuzzi G, Benigni A, Remuzzi A. Mechanisme of progression and regression of renal lesions of chronic nephropathies and diabetes. J Clin Invest. 2006; 116 : 28896

11. Sacks DB, Arnold M, Bakris GL, Bruns DE, Horvath AR, Kirkman MS et al. Albuminuria (formerly micro-albuminuria) guidelines and recommendations for laboratory analysis in the diagnosis and management of diabetes mellitus. Clin Chem. 2011;57:39-42

12. Miller G, Bruns DE, Hortin GL, Sanberg S, Aakre KM, McQueen MJ et al. Current issues in measurement and reporting of urinary albumin excretion. Clin Chem. 2009;55:24-38.

13. NKF KDOQI Guidelines. KDOQI clinical practice guideline and clinical practice recommenddation for diabetes and chronic kidney disease. Diakses dari www.kdoqi.org

14. Schieppati A and Remuzzi G. Chronic renal disease as a public health problem: epidemiology, social, and economic implications. Kidney Int. 2005; 68: 7-10 
15. Moorhead JF, Chan MK. Lipid nephrotoxicity in chronic progressive glomerular and tubulointerstitial disease. Lancet 1982:2: 1309-11

16. Murray KR, Granner KD, Mayes AP, Rodwell WV. Pengangkutan dan Penyimpanan Lipid. Dalam: Biokimia Harper. Edisi 25. Jakarta: Penerbit Buku Kedokteran EGC; 2003; p254-75

17. Hass EM, Atti DA. The regulation of Apo B metabolism by insulin. Trends endocrinol metab 2013:24(8):391-7

18. Sundaram M, Yao Z. Recent progress in understanding protein and lipid factors affecting hepatic VLDL assembly and secretion. Nutr metab 2010:7:35

19. Irshad M, Dubey R. Apolipoproteins and their role in different clinical conditions: an overview. Indian J Biochem Biophys 2005;45:73-80.

20. Samuelsson $O$ et al. Complex apolipoprotein B - containing lipoprotein particles are associated with a higher rate of progression of human chronic renal insufficiency. $\mathrm{J} A \mathrm{~m}$ Soc Nephrol.1998;9:1482-8

21. Uniyal R, Ahuja R, Ojha P. Correlation of ApoB/Apo A1 with diabetic nephropathy. Bruney Int Med J. 2012;8(4):179-184

22. Adi S, Pranoto A, Tjokroprawiro A, Murtini S, Sutjahjo A, Supiansyah. Correlation between Apo $B$ with microalbuminuria in patient with type 2 diabetes mellitus. Abstrak. 2012

23. Nakhjavani et al. Albuminuria and its correlates in an Iranian type 2 diabetic population. Lipid health dis 2008;7:28

24. Tseng $\mathrm{CH}$. Lipid abnormalities associated with urinary albumin excretion rate in Taiwanese type 2 diabetic patients. Kidney Int 2005;67:1547-53A

25. Norma S, Azmi MT, Rotina AB. Factors that influence albuminuria among type 2 diabetes mellitus at primary healthcare clinics in negeri sembilan 2007. J Commun Health.2010;16:21-32.

26. Bonakdaran $S$, Hami $M$, Shakeri MT. Hyperuricemia and albuminuria in patients with type 2 diabetes mellitus. Iran $\mathrm{J}$ kidney dis 2011;5:21-4.

27. Gupta KK, Patel ML, Sachan R, Uniyal R. Clinical Correlation betwen ApoB / ApoA1 Ratio in Type 2 Diabetic Nephropathy - A Tertiary Centre Experience. IJSRP 2012;9: 2250-3
28. Behradmanesh S, Horestani MK, Nasri H. Association of serum uric acid with proteinuria in type 2 diabetic patients. J Res Med Sci 2013;18:44-6.

29. Hui-Mei C, Wen-Wen S, Yong-Chun G, YiDe $Z$, Hong-Lang $X$, Zhi-Hong $L$. The relationship between obesity and diabetic nephropathy in China. BMC Nephrol 2013;14:69-75

30. Pradip R, Jayanta D. Changes in microalbuminuria in relation to glycosylated haemoglobin and duration in type 2 diabetes mellitus. Ind M Gaz 2012:394-9

31. Noha A, Gamal A. Evaluation of oxidative stress markers and vascular risk factor in patient with diabetic nephropathy. Cell Biochem Func 2012;30(4):328-34

32. Sylvia HL et al. Association of apolipoprotein $B$ with incident type 2 diabetes in an Aborigynal Canadian population. Clin Chem 2010;56(4): 666-70

33. Kundu PO, Alaupovic P, Samuelsson $O$. Lippoprotein Abnormalities as a Risk Factor for Progressive Nondiabetic Renal Disease. Kidney Int 1999; 71: 14-7

34. Syrjanen $\mathrm{J}$ et al. Hypertrigliseridemia and hyperuricemia risk factor for progression of IgA nephropathy. Nephrol Dial Transplant. 2000;15:34-42

35. Hsu CC, Chang HY, Huang MC. HbA1C variability is associated with microalbuminuria development in type 2 diabetes: a 7-year prospective cohort study. Diabetologia 2012; 55:3163-72

36. Pradip $R$, Jayanta $D$. Changes in microalbuminuria in relation to glycosylated haemoglobin and duration in type 2 diabetes mellitus. Ind M Gaz 2012:394-9

37. Noura A, Farah A, Sadia A. Dyslipidemia and its correlation with type 2 diabetic patients at different stage of proteinuria. Biomed Res 2014;25(3):327-1

38. Chul-Woo Y, Jung TP, Yon SK, Yong LK, Yil-Seob L, Yoon-Sun, et al. Prevalence of diabetic nephronpathy in primary care type 2 diabetic patients with hypertension: data from the Korean Epidemiology study on hypertension III (KEY III Study). Nephrol Dial Transplant. 2011;26: 3249-55.

39. Van Buren PN, Tato R. Hypertension in diabetic nephropathy: Epidemiology, mechanism, and management. Adv Chronic Kidney Dis. 2011;18(1):28-41. 
40. Bruno G, Marletti F. Progression to overt nephropathy in type 2 diabetes. Diabetes care. 2007:26 (7):2150-5

41. Chin $P$ et al. Frequency of albuminuria in primary care: a cross sectional study. Kidney int 2007;14: 107-13

42. Lam KSL, Pang WC, Wat MS, Lauder IJ, Janus ED. Apolipoprotein (a) levels and phenotypes in NIDDM patients with microalbuminuria and albuminuria. Nephrol Dial Transplant. 1996;11:2229-2236
43. Rizk MN, Aly H, Samir P, Mofty H, Osama KA. Apolipoprotein B level and diabetic microvascular complications: is there correlation? Egypt J Int Med. 2013;25:13742

44. Corsetti PJ, Gansevoort TR, Bakker JL, Sparks CE. Apolipoprotein B attenuates albuminuria associated cardiovascular disease in prevention of renal and vascular endstage disease (PREVEND) participants. J Am Soc Nephrol. 2014;25:1-10 